\title{
Predictive ability of accruals before and after IFRS in the Brazilian stock market
}

\author{
Terence Machado Boina ${ }^{1}$ \\ (D) https://orcid.org/0000-0001-9624-1703 \\ Email: tmboina@ufrj.br
}

\author{
Marcelo Alvaro da Silva Macedo ${ }^{1}$ \\ Email: malvaro.facc.ufrj@gmail.com
}

'Universidade Federal do Rio de Janeiro, Faculdade de Administração e Ciências Contábeis, Programa de Pós-Graduação em Ciências Contábeis, Rio de Janeiro, RJ, Brazil

Received on 07.26.2017 - Desk acceptance on 09.09.2017 - $3^{\text {rd }}$ version approved on 01.17.2018 - Ahead of print on 08.02.2018 Associate Editor: Eliseu Martins

\begin{abstract}
This study aimed to analyze and assess the predictive ability of discretionary accruals (DAs) and non-discretionary accruals (NDAs) for forecasting future cash flows before and after the convergence with International Financial Reporting Standards (IFRS) in Brazil. The study is warranted due to the scarcity of research in Brazil on the subject and is relevant because it aims to shed light on whether the changes occurring due to convergence with IFRS in Brazil have improved accounting quality. The accounting choices of managers and accountants in the Brazilian stock market, enabled by IFRS, contribute to an apparent improvement in accounting quality in terms of reliability, the faithful representation of entities' equity and financial positions, and in particular, the predictive ability for forecasting future cash flows. The population was composed of publicly traded companies listed on the Bovespa and São Paulo Stock, Commodities, and Futures Exchange (BM\&FBovespa) in 2004 to 2007 and 2010 to 2015. The non-probability convenience sample is composed of 715 enterprises, once companies from the "finance and insurance" and "funds" sectors and even those considered as "holding" were excluded. The data were pooled by year, as they contain different companies over the time series (unbalanced panel data). The DAs and NDAs produced prior to full convergence with IFRS are negative and statistically significant for predicting future cash flows in the Brazilian stock market, which indicated opportunistic/contractual earnings management. One of the possible explanations for this would be the influence of government tax authorities on Brazilian accounting norms, which could induce managers to manipulate accounting results with the aim of reducing earnings in order to pay fewer taxes, for example. The DAs and NDAs produced after IFRS are positive and statistically significant for predicting future cash flows in the Brazilian stock market, signaling the motivation of discretionary accounting choices under the informational aspect. Current DAs and NDAs add informational power compared to current aggregate accruals. It has also been observed that the current DAs and NDAs originating after IFRS in Brazil, compared to current aggregate accruals, have an informational gain in relation to those produced before.
\end{abstract}

Keywords: accounting quality, predictive ability, accruals, IFRS, cash flow. 


\section{INTRODUCTION}

Various authors, such as Paton and Littleton (1940), and also Technical Pronouncement n. 26 of 2011 of the Accounting Pronouncements Committee (CPC, 2011), highlight that one of the main objectives of accounting statements is to provide information to users for their evaluations and economic decision making regarding companies' equity, financial, and economic positions. Watts and Zimmerman (1986) and Lopes and Martins (2007) add that in order to be relevant accounting statements must help in forecasting future cash flows.

Thus, within the academic sphere, various studies have gone on to estimate future cash flow values to serve as an input for decision makers, especially analysts, investors, and creditors. Barth, Cram, and Nelson (2001), for example, sought to analyze the pronouncement from the Financial Accounting Standards Board (FASB, 1978) that earnings would be a more suitable performance measure for predicting future cash flows than current cash flows themselves.

Usually, academic studies use operating cash flows (OCFs) as a proxy for cash flow, since they refer to the main revenue, cost, and expense generating activities of an entity. Thus, the studies are generally restricted to examining the ability to predict future OCFs based on historical data on accounting variables, such as income or loss from the accounting period (NI) and OCF itself.

NI differs from OCF in some cases due to the accruals basis of accounting used for economic events, in which revenues and expenses are recognized in the accounts independently of the financial realization (inflows or outflows of cash) of the transactions and/or events. Thus, according to Lopes and Martins (2007), there are temporal differences between the recognition of the economic impacts on the result and their reflection on cash flows, with these differences being called accruals (ACCs). ACCs are the essence of the informational content of accounting (Lopes \& Martins, 2007), since they reduce noise from intertemporal allocations in OCF (Dechow, Kothari \& Watts, 1998), seeking to eliminate receipts and payments, revenues and expenses from events from different periods.

Consequently, using statistical models researchers have gone on to test the ascendance of aggregate or disaggregated ACCs in predicting cash flows, specifically whether they add or not to the ability to predict OCFs
(Barth et al., 2001). Among the ways of analyzing ACCs, their aggregation or disaggregation stand out, as well as their time lapse (current or non-current), their origin and application of resources (liabilities or assets), operational questions (operational cycle and financial expenses), and their discretion (or non-discretion).

Some Brazilian studies, such as Machado, Silva Filho, and Callado (2014), and Boina, Martins, Costa, and Macedo (2016a), have also sought to investigate the predictive ability of accounting variables such as OFC, NI, and ACCs, for predicting future cash flows. In general, the results of the studies indicate the supremacy of the informational content of OCF in relation to NI for predicting future OCFs and also that aggregate and disaggregated ACCs add informational content to current OCF for predicting future cash flows.

An important aspect of the studies developed in recent years relates to the change in accounting rules adopted in the local environment. Various researchers, such as Barth, Landsman, and Lang (2008) and Silva (2013), have investigated the impact of using International Financial Reporting Standards (IFRS) in terms of cost of capital, financial indicators, accounting variables, qualitative characteristics of accounting information etc.

There are few academic discussions about the predictive ability of ACCs disaggregated into discretionary and nondiscretionary for predicting future cash flows, given that only a few studies on this were identified in the Google Scholar ${ }^{\circledast}$ and Capes Journals Portal platforms, including Brochet, Nam and Ronen (2007), and Olfa and Hamadi (2015). In Brazil, no study on this was identified.

Studying the predictive ability of ACCs, segregated into discretionary and non-discretionary, is especially appropriate for analyzing how the accounting choices practiced by managers under different rules in the Brazilian stock market influence the results, especially future cash flows, presented to the various stakeholders.

In light of this lack of research within the academic field regarding the predictive ability of DAs and NDAs in relation to future cash flows, the following research problem is proposed: what is the predictive ability of current ACCs disaggregated into discretionary and nondiscretionary for estimating future OCFs before and after 
convergence with IFRS in Brazil? In light of the above, this study aimed to analyze and assess the predictive ability of DAs and NDAs in forecasting future OCFs before and after convergence with IFRS in Brazil.

It was verified that the DAs and NDAs produced before IFRS came into place are negative and statistically significant for predicting future cash flows in the Brazilian stock market, which indicated earnings management of the opportunistic/contractual type. One of the possible explanations for this would be the influence of government tax authorities on Brazilian accounting norms, which could induce managers to manipulate accounting results with the aim of reducing profits in order to pay fewer taxes, for example.
The DAs and NDAs produced after IFRS, with less ascendance of the tax authorities, are positively and statistically significant for predicting future cash flows in the Brazilian stock market, indicating the motivation of discretionary accounting choices under the informational aspect. It was also identified that the current DAs and NDAs originating after IFRS, in comparison with current aggregate accruals, have an informational gain in relation to those produced before. Thus, the accounting choices of managers and accountants in the Brazilian stock market, enabled by IFRS, contribute to an apparent improvement in accounting information quality in terms of reliability, the faithful representation of entities' equity and financial positions, and in particular, the predictive ability for estimating future cash flows.

\section{LITERATURE REVIEW}

\subsection{Positive Accounting Theory}

Watts and Zimmerman (1986) systematized the positive approach in accounting research and affirmed that the aim of accounting theory is to explain and predict accounting practices. In other words, the relevance lies in understanding the role of accounting and, from an information-based perspective, the informative content derived from the accounting practices that can provide support to stakeholders' decision making processes. For this, an economic approach involving hypothesis acceptance or rejection tests was used, employing mathematical models in order to highlight the reasons for choices of accounting practices and to predict the behaviors of non-observable phenomena.

According to Watts and Zimmerman (1986), the recognition, measurement, and disclosure of accounting information are generally guided by partial decisions, resulting from economic incentives that maximize the needs of interested parties. Managers usually ignore the fact that in earnings managements accounting choices should be guided by the economic principals of the company's business.

Since one of the aims of accounting, according to Watts and Zimmerman (1986), is to predict accounting practices and their effects, various studies have been developed regarding the predictive ability of accounting variables. Among these, those that have aimed to predict future cash flows stand out. Table 1 summarizes information on some of the main international and Brazilian studies developed in relation to the theme of the predictive ability of accounting variables.

The paradigmatic study from Sloan (1996) also stands out, which investigated the relationship between ACCs and current cash flows and future income/losses, as well as the relationship between these and the prices of shares in the U.S. market. Unlike what is predicted by the efficient market hypothesis (share prices fully reflect the information available), the author concluded that the evidence indicates that investors are not fully able to identify the properties of ACCs and current cash flows when pricing shares.

Dechow and Dichev (2002) highlighted that the quality of ACCs (i) reduces by the magnitude of the estimation error (intentional or not) of the ACCs and (ii) is positively related to the persistence of income/ losses. In addition, the authors pointed out that the quality of current ACCs is related with the realization of past, present, and future cash flows. 
Table 1

Summary of some of the main studies on the predictive power of accounting variables

\begin{tabular}{|c|c|}
\hline Reference & Summary of the Results \\
\hline $\begin{array}{l}\text { Finger } \\
(1994)\end{array}$ & $\begin{array}{l}\text { Between } 1935 \text { and 1987, in the U.S. market, income or loss for the accounting period (NI) and operating cash flow (OCF) } \\
\text { have a similar predictive ability for long term time horizons, but OCF is slightly superior to NI for short term time horizons. }\end{array}$ \\
\hline $\begin{array}{l}\text { Dechow et al. } \\
\text { (1998) }\end{array}$ & $\begin{array}{l}\text { Between } 1963 \text { and 1992, in the U.S. market, NI is a better predictor of future OCFs than current OCFs themselves, and } \\
\text { companies with longer operational cycles better explain the supremacy of NI over OCF. }\end{array}$ \\
\hline $\begin{array}{l}\text { Barth et al. } \\
\text { (2001) }\end{array}$ & $\begin{array}{l}\text { Between } 1987 \text { and 1996, in the U.S. market, there was a significant improvement in the predictive ability of future OCFs } \\
\text { with the disaggregation of total accruals (ACCs) into operational assets and liabilities and long term assets. }\end{array}$ \\
\hline $\begin{array}{l}\text { Kim and Kross } \\
\text { (2005) }\end{array}$ & $\begin{array}{l}\text { Between } 1973 \text { and 2000, in the U.S. market, the role of current NI in predicting future OCFs improved over time for one } \\
\text { year time horizons, however this relationship tends not to improve beyond one year time horizons. }\end{array}$ \\
\hline $\begin{array}{l}\text { Farshadfar, } \mathrm{Ng}, \\
\text { and Brimble } \\
\quad(2008)\end{array}$ & Between 1992 and 2004, in the Australian market, OCF has more predictive power than $\mathrm{NI}$ in forecasting future OCFs. \\
\hline Ebaid (2011) & $\begin{array}{c}\text { Better } 1999 \text { and 2007, in the Egyptian market, NI has a greater predictive ability than OCFs for estimating future OCFs and } \\
\text { disaggregated ACCs improve the predictive ability of OCFs. }\end{array}$ \\
\hline $\begin{array}{l}\text { Malacrida, } \\
\text { Yamamoto, Lima, } \\
\text { and Lima } \\
\text { (2008) }\end{array}$ & $\begin{array}{l}\text { Between } 1999 \text { and 2005, in the Brazilian market, OCFs have a greater predictive ability than NI for estimating future OCFs, } \\
\text { ACCs have a predictive ability additional to current OCF for estimating future OCFs, and OCF with disaggregated ACCs } \\
\text { have a greater predictive ability for future OCFs than the aggregate ACCs model. }\end{array}$ \\
\hline $\begin{array}{l}\text { Costa and Afonso } \\
\qquad(2015)\end{array}$ & $\begin{array}{l}\text { Between } 2005 \text { and 2013, in Brazilian insurers, NI, ACCs, and OCF have the ability to predict future OCFs, and given the } \\
\text { results of the adjusted } \mathrm{R}^{2} \text { and of the Akaike informational criteria, there are doubts about whether ACCs increase the ability } \\
\text { to predict OCFs. }\end{array}$ \\
\hline $\begin{array}{l}\text { Boina et al. } \\
\text { (2016a) }\end{array}$ & $\begin{array}{l}\text { Between } 2010 \text { and 2014, in electrical energy providing companies, current OCF has a greater predictive ability than } \\
\text { current NI for estimating OCFs for subsequent periods and current aggregate ACCs and some disaggregated ACCs increase } \\
\text { the predictive ability of current OCFs for predicting the OCFs for subsequent periods. }\end{array}$ \\
\hline
\end{tabular}

Source: Elaborated by the authors.

Some studies, such as that of Chen, Tang, Jiang, and Lin (2010), have also associated the predictive ability of accounting variables with the quality of the accounting information generated in certain institutional environments, especially in contexts of convergence with IFRS.

\subsection{Quality of Accounting Information}

The quality of accounting information is, in general, related to the economic, political, and social context in which a company operates (Dechow \& Schrand, 2004). Emerging countries, such as Brazil, tend to have less developed capital markets and more vulnerable and less consolidated regulatory environments than developed countries, as is the case of the United States (Ebaid, 2011).

Therefore, as Brazil is characterized as a code-law country, political actions by the State, in relation to taxation, and by other interested parties, such as unions, auditing companies, investors, and financers, can also influence the production of accounting information, and therefore the portrayal of economic facts. Thus, in light of the pressures exerted by such stakeholders, some skepticism about the quality of Brazilian accounting information as a predictive measure is warranted, given the possible existence of privileges for some to the detriment of others, despite the recent obligatory adoption of IFRS in Brazil.

Different studies, highlighted in Table 2, have sought to investigate the impacts of the changes derived from the accounting convergence with IFRS. However, there is no consensus regarding the effects, with some studies not showing any significant impact and others indicating improvements in the quality of accounting information (Costa \& Afonso, 2015). 
Table 2

Summary of some of the main studies on impacts of the convergence with International Financial Reporting Standards

\begin{tabular}{cr}
\hline Reference & Summary of the results \\
$\begin{array}{r}\text { Tendeloo and Vanstraelen } \\
(2005)\end{array}$ & $\begin{array}{r}\text { Between } 1999 \text { and 2001, in the German market, there was greater earnings management after IFRS adoption, but to } \\
\text { a lesser extent when the company was audited by a Big Four external auditing company. }\end{array}$ \\
Barth et al. (2008) & $\begin{array}{r}\text { Between } 1994 \text { and 2003, in } 21 \text { countries, there was an increase in the quality of accounting information from } \\
\text { an earnings management, conservatism, and value relevance point of view and a strong association between } \\
\text { accounting information and share prices and returns after IFRS adoption. }\end{array}$ \\
\hline
\end{tabular}

Ahmed, Neel, and Wang (2013)
Between 2002 and 2007, in 20 countries, there was insufficient evidence that IFRS adoption produces improvements in accounting quality, from an earnings management and conservatism point of view.

Between 2000 and 2011, in the Brazilian and European markets, the quality of accounting information did not

Paulo, Girão, Carter, and Souza (2013) significantly improve in relation to the period before IFRS, from a persistence, conservatism, earnings management, and errors in total accruals (ACCs) point of view.
Silva (2013)

Between 2000 and 2011, in the Brazilian market, there was a decrease in ACCs, an increase in conditional conservatism, an increase in the relevance and timeliness dimensions of the quality of accounting information, and a reduction in the cost of capital after the complete adoption of IFRS.

Between 2006 and 2011, in the Brazilian market, there was an increase in the explanatory ability of NI and of

Machado et al. (2014) operating cash flow (OCF) combined with ACCs in the period after convergence in Brazil and it was found that ACCs have additional informative power in predicting future OCFs.

Boina, Jesus, Soares, and Macedo (2016b)
Between 2005 and 2007 and 2010 and 2014, in the Brazilian market, there was a consolidation of the supremacy of the informational content of current OCF in relation to the income or loss for the current accounting period in predicting future OCFs and it was found aggregate ACCs and some disaggregated ACCs add informational content to current OCF for predicting future cash flows after IFRS adoption.

Source: Elaborated by the authors.

It is noted that, among the dimensions of accounting information quality, earnings management stands out (Burgstahler, Hail \& Leuz, 2006).

\subsection{Earnings Management}

According to Martinez and Cardoso (2009), earnings management relates to the choice of accounting practices or operational decisions taken with the intention of communicating different accounting numbers from those that would be disclosed without the adoption of such practices or decisions. Subsequently, Martinez (2013) defined earnings management as the use of management discretion in relation to accounting choices, to operational decision making, and to the selection of the criteria for presenting income statements, within the limits of the accounting rules, aimed at influencing perceptions about underlying economic facts.

These accounting choices were defined by Fields, Lys, and Vicent (2001) as any decision with the primary purpose of influencing accounting results in a particular way. Also according to the authors, these choices can, for example, induce contractual arrangements, asset pricing, and external agents.
In general, according to Guay, Kothari, and Watts (1998) and Chaney, Faccio, and Parsley (2011), managers are motivated to use discretionary accounting choices under two aspects: informational and opportunistic/ contractual. In the informational aspect, managers generally use accounting rule flexibilities to reduce risks and increase the relevance and the reliability of the accounting information communicated in order to improve its predictive utility and faithfully represent an economic phenomenon (Badertscher, Collins \& Lys, 2012; Subramanyam, 1996). In the opportunistic or contractual aspect, managers usually make (discretionary) accounting choices to avoid representing the real economic performance of the company, sometimes to minimize contractual costs (transactional, agency, informational, renegotiation, etc.), in order to favor their own interests to the detriment of other stakeholders (Dechow \& Skinner, 2000; Teoh, Welch \& Wong, 1998).

Unlike the informational aspect, the opportunistic/ contractual aspect increases risks and reduces the predictive ability of ACCs in relation to future cash flows, because the discretionary choices in the accounting process tend to induce bias in the numbers reported (Badertscher et al., 2012). 
Among the accounting information that is prone to discretion, DAs stand out, measured and recorded in the accounts in accordance with managers' and accountants' choices (Healy \& Wahlen, 1999). NDAs usually relate to company conditions or activity levels (more objective), while DAs are the consequence of management choices (more subjective) (Christensen, Frimor \& Sabac, 2012).

Brochet et al. (2007) found that DAs are negative and statistically related with total ACCs and concluded that manager and accountant discretion generates a lower contribution to predicting cash flows, indicating an opportunistic outlook in the US market, between 1987 and 1996.

In turn, Olfa and Hamadi (2015) found that in the United Kingdom, between 1998 and 2008, DAs had a positive impact on the estimation of future OCFs in the period after IFRS adoption in relation to the one before (predominance of the informational aspect (positive sign and significant) of DAs with regards to future OCFs); this was not found with regards to France, between 1990 and 2008, which could be explained, at least in part, by the legal regime adopted in that country.

Total ACCs can be calculated from a balance sheet or a cash flow statement (CFS) perspective (Paulo, 2007). The first method is related with the assumption that changes in current capital accounts are articulated with the components of revenue and expense ACCs in the income statement for the accounting period. In this case, the ACCs are calculated as the difference between the variation in current operating assets (except cash flow and its equivalents) and current operating liabilities (except short term financing), minus depreciation and amortization expenses for the period (Paulo, 2007). Yet, this assumption is weakened when non-operational events and transactions occur, such as reclassifications, mergers, acquisitions, and the sale of businesses, changes in accounting criteria, foreign currency transactions, etc. (Hribar \& Collins, 2002).

From the CFS perspective, the approach used in this study, ACCs are calculated as the different between the NI and the OCF for the period (Hribar \& Collins, 2002; Paulo, Martins \& Corrar, 2007), as according to equation 1. This approach is warranted in environments with intense mergers, acquisitions, and incorporations processes, such as the Brazilian one in the years analyzed in this study (PriceWaterhouseCoopers, 2015). This choice can also be considered a limitation of the study, given that in the original models from Kothari, Leone, and Wasley (2005) and Dechow, Hutton, Kim, and Sloan (2012), the ACCs were calculated indirectly, using the balance sheet perspective.

$$
A C C_{i, t}=N I_{i, t}-O C F_{i, t}
$$

in which $A C C$ are total accruals, $N I$ is the income or loss for the accounting period, $O C F$ is the operating cash flow, $i$ is the unit analyzed, and $t$ is the analysis period.

In this study, to estimate the DAs and NDAs, the models from Kothari et al. (2005) and Dechow et al. (2012) were used, as highlighted below.

\section{Kothari et al. (2005) Model}

$$
A C C_{i, t}=\alpha\left(\frac{1}{A_{i, t-1}}\right)+\beta_{1}\left(\Delta \operatorname{Rev}_{i, t}-\Delta A C_{i, t}\right)+\beta_{2}\left(F A_{i, t}\right)+\beta_{3}\left(R O A_{i, t-1}\right)+\varepsilon_{i, t}
$$

in which $A C C$ is total accruals, $A$ is total assets, $\triangle R e v$ is the variation in net revenues, $\triangle A C$ is the variation in accounts receivable, $F A$ is fixed assets, $R O A$ is return on assets, $i$ is the unit analyzed, $t$ is the analysis period, and $\varepsilon$ is the error term (DA).

Dechow et al. (2012) Model

$$
A C C_{i, t}=\alpha\left(\frac{1}{A_{i, t-1}}\right)+\beta_{1}\left(\Delta \operatorname{Rev}_{i, t}-\Delta C R_{i, t}\right)+\beta_{2}\left(F A_{i, t}\right)+\beta_{3}\left(A C C_{i, t-1}\right)+\varepsilon_{i, t}
$$

in which $A C C$ is total accruals, $A$ is total assets, $\Delta R e v$ is the variation in net revenues, $\triangle C R$ is the variation in current receivables, $F A$ is fixed assets, $i$ is the unit analyzed, $t$ is the analysis period, and $\varepsilon$ is the error term (DA). 


\section{METHODOLOGY}

\subsection{Population and Sample}

The population was constituted of publicly traded companies listed on the Bovespa and the São Paulo Stock, Commodities, and Futures Exchange (BM\&FBovespa) in 2004 to 2007 and 2010 to 2015, respectively. The nonprobability convenience sample considered companies that presented data on the required variables in each of the years analyzed. The probable outliers, as suggested by Fávero, Belfiore, Silva, and Chan (2009, p. 55-56), were removed from the samples considering the upper $(\mathrm{Q} 3)$ and lower (Q1) quartiles, also known as interquartile range (Q3-Q1). Thus, an observation will be considered an outlier if it is below the lower quartile more than three times the interquartile range. The same is applied to the observations that were above the upper quartile more than three times the interquartile range.

In this study, data were used from before 2008 and after 2009 as periods alluding to the non-use and complete use of IFRS in Brazil, respectively. Since the Brazilian Securities and Exchange Commission (CVM, 2005) established that Brazilian publicly traded companies should publish their CFSs, the years from 2005 to 2007 were used as the preconvergence period. The data gathered after convergence with IFRS in Brazil referred to the years from 2010 to 2015. Due to the only partial obligatory adoption of IFRS, 2008 and 2009 were not considered in this study.

Of the population of 972 companies, 159 belonging to the "finance and insurance" and "funds" sectors, in accordance with the classification of Economatica ${ }^{\circledR}$, were removed due to them having specific characteristics, for example in their accounting treatment of financial instruments, consolidation, provision for doubtful accounts, and leasing, regulated by the Brazilian Central Bank. Thus, in light of the accounting idiosyncrasies of these companies, it is possible to affirm that the process itself of forming their results is usually different from other companies.

Ninety-eight companies considered holding, according to the description in the footnotes, were removed since their revenues predominantly refer to equity equivalence (unlike the others, whose sales revenues are primarily derived from goods and from service providing) and they also do not usually have fixed assets, which could severely harm the results of DAs and NDAs derived from the Kothari et al. (2005) and Dechow et al. (2012) models. With this, the sample was composed of 715 companies.

The data employed in the study are essentially secondary and collected using the Economatica ${ }^{\oplus}$ database. They were pooled in a cross section and time series by year, since the data used in the models in this study contain different companies over the time series (unbalanced panel data).

\subsection{Hypotheses}

According to Biddle, Seow, and Siegel (1995), in the field of accounting research, the evaluation of incremental content stands out, which examines whether an accounting measure provides supplementary informational content to that offered by another measure. When accounting statement users come across different standardizations, for the economic scenario or involving different possibilities for measures, for example, it is interesting to study informational content in incremental terms.

Many studies evaluate the incremental content of accounting variables in the addition of informational content (such as aggregate and disaggregated ACCs) in relation to another variable (such as NI and OCF), such as Barth et al. (2001), Malacrida et al. (2008), and Boina et al. (2016a). As highlighted in the literature review in this paper, in these studies it was concluded that there is an increase in informational power when other variables are added in relation to the original predictive equation, and when there is disaggregation of variables, there is a greater addition of informational power.

In turn, studies in various countries of the world have analyzed the quality of accounting information, under different aspects, produced after complete convergence with IFRS in relation to that produced before convergence, such as Barth et al. (2008) and Machado et al. (2014). As highlighted in the literature review in this paper, many of these studies have observed benefits with regards to the accounting information produced after IFRS adoption.

In light of the above, the following research hypotheses were tested:

a. $\mathrm{H}_{1}$ : the current ACCs disaggregated into discretionary and non-discretionary, derived from the Kothari et 
al. (2005) and Dechow et al. (2012) models, add informational power in comparison with the current aggregate ACCs.

b. $\mathrm{H}_{2}$ : the current ACCs disaggregated into discretionary and non-discretionary, derived from the Kothari et al. (2005) and Dechow et al. (2012) models and originating after complete convergence with IFRS in Brazil (from 2010), in comparison with the current aggregate ACCs, have an informational gain in relation to those produced before.

\subsection{Study Variables}

The values of the dependent variables are in $t$ and those of the independent variables are in $t-1$, with there being two periods: before (2004-2007) and after (2011-2015) IFRS. Influenced by Barth et al. (2001), it is noted that the values of the dependent and independent variables were adjusted by the mean of total assets between the start and the end of the period analyzed.

In this study, the models below were used to test $\mathrm{H}_{1}$ (models 1 and 2 ) and $\mathrm{H}_{2}$ (models 3 and 4):

Model 1

$$
O C F_{i, t}=\alpha+\beta_{1} O C F_{i, t-1}+\beta_{2} A D_{i, k, t-1}+\beta_{3} N D A_{i, k, t-1}+\varepsilon_{i, t}
$$

Model 2

$$
O C F_{i, t}=\alpha+\beta_{1} O C F_{i, t-1}+\beta_{2} A C C_{i, t-1}+\varepsilon_{i, t}
$$

Model 3

$$
\begin{aligned}
O C F_{i, t}=\alpha & +\beta_{1} O C F_{i, t-1}+\beta_{2} O C F_{i, t-1} \times I F R S+\beta_{3} D A_{i, k, t-1}+\beta_{4} D A_{i, k, t-1} \\
& \times I F R S+\beta_{5} N D A_{i, k, t-1}+\beta_{6} N D A_{i, k, t-1} \times I F R S+\varepsilon_{i, t}
\end{aligned}
$$

Model 4

$$
O C F_{i, t}=\alpha+\beta_{1} O C F_{i, t-1}+\beta_{2} O C F_{i, t-1} \times I F R S+\beta_{3} A C C_{i, t-1}+\beta_{4} A C C_{i, t-1} \times I F R S+\varepsilon_{i, t}
$$

in which $O C F$ is operating cash flow, $D A$ is discretionary accruals, $N D A$ is non-discretionary accruals (subtraction between $A C C$ and $A D$ - error terms of the ACC estimation model), $A C C$ is total aggregate accruals, IFRS is a dummy variable ( 1 when it refers to the period after 2010 and 0 otherwise), $i$ is the unit analyzed, $k$ is the model considered for calculating $D A$ and $N D A, t$ is the analysis period, and is the error term.

\subsection{Limitations of the Research}

Among the limitations of the research, it is noted that the existence of ACCs classified in operational activities for the formation of OCFs and that may not really be from company operational activities, such as interest paid and received, dividends, and interest received on own capital, was not considered. This may influence the results of the research, given that there may not be harmony in the data on the companies analyzed with regards to OCFs; that is, some may consider some of these ACCs as operational activities and others may not.

Another limitation of the research relates to the ACC estimation models employed: Kothari et al. (2005) and Dechow et al. (2012). It is noted that, besides the DAs, the error terms may contain usual NDAs. In the period subsequent to complete convergence with IFRS, some of the variables considered non-discretionary in these models contain discretion, to a greater or lesser degree. For example, fixed assets are periodically reduced to recoverable value in Brazil, with the recording of potential losses in the result for the accounting period or in reevaluation reserves, depending on the case. This type of test, as a general rule, involves the professional judgment of company accountants and managers to reflect the economic essence of the assets. 


\section{PRESENTATION AND ANALYSIS OF THE RESULTS}

\subsection{ACC Estimation Models}

As shown in tables 3 and 4 , the means and medians of the ACC variable were positive in the period before convergence with IFRS in Brazil. On the other hand, in the period after convergence, the values of the means and medians of the ACC variable were negative and closer to
0 , indicating a smaller difference between NI and OCF.

In light of this, a difference of means test between the ACCs before and after IFRS adoption in Brazil was carried out. The null hypothesis that the difference between the means would be equal to 0 was rejected ( $p$-value $=0.0000$ ), indicating differences between the means of the ACCs in these periods.

Table 3

Descriptive statistics - Discretionary accruals (DAs) and non-discretionary accruals (NDAs) estimated using the Kothari et al. (2005) model

\begin{tabular}{cccccccc}
\hline Variables & Period & Minimum & Maximum & Mean & Median & Standard deviation \\
\hline \multirow{2}{*}{ OCF $_{\mathrm{t}}$} & $2005-2007$ & 0.00000 & 0.17819 & 0.013401 & 0.00000 & 0.021594 \\
\cline { 2 - 7 } & $2012-2015$ & 0.00000 & 0.33158 & 0.082599 & 0.069949 & 0.067003 \\
\hline \multirow{2}{*}{ OCF $_{\mathrm{t}-1}$} & $2004-2006$ & 0.00000 & 0.17019 & 0.0096173 & 0.00000 & 0.019693 \\
\cline { 2 - 7 } & $2011-2014$ & 0.00000 & 0.34589 & 0.088059 & 0.073715 & 0.069050 \\
\hline \multirow{2}{*}{$\mathrm{ACC}_{\mathrm{t}-1}$} & $2004-2006$ & -0.070572 & 0.54004 & 0.072281 & 0.050306 & 0.076100 \\
\hline \multirow{2}{*}{$\mathrm{DA}_{\mathrm{t}-1}$} & $2011-2014$ & -0.28035 & 0.51241 & -0.018972 & -0.022159 & 0.074148 \\
\hline \multirow{2}{*}{$\mathrm{NDA}_{\mathrm{t}-1}$} & $2004-2006$ & -0.39443 & 0.29320 & -0.049030 & -0.044190 & 0.098408 \\
\cline { 2 - 7 } & $2011-2014$ & -0.41583 & 0.29517 & -0.069143 & -0.075340 & 0.087359 \\
\hline
\end{tabular}

Source: Elaborated by the authors.

Table 4

Descriptive statistics - Discretionary accruals (DAs) and non-discretionary accruals (NDAs) estimated using the Dechow et al. (2012) model

\begin{tabular}{|c|c|c|c|c|c|c|}
\hline Variables & Period & Minimum & Maximum & Mean & Median & Standard deviation \\
\hline \multirow{2}{*}{$\mathrm{OCF}_{\mathrm{t}}$} & 2005-2007 & 0.00000 & 0.17819 & 0.014169 & 0.00000 & 0.022107 \\
\hline & 2012-2015 & 0.00000 & 0.33158 & 0.082703 & 0.070014 & 0.067071 \\
\hline \multirow{2}{*}{$\mathrm{OCF}_{\mathrm{t}-1}$} & 2004-2006 & 0.00000 & 0.17019 & 0.010852 & 0.00000 & 0.020623 \\
\hline & 2011-2014 & 0.00000 & 0.34589 & 0.088321 & 0.073987 & 0.069312 \\
\hline \multirow{2}{*}{$\mathrm{ACC}_{\mathrm{t}-1}$} & 2004-2006 & -0.070572 & 0.51931 & 0.066840 & 0.047338 & 0.069920 \\
\hline & 2011-2014 & -0.28035 & 0.45277 & -0.019764 & -0.022523 & 0.072719 \\
\hline \multirow{2}{*}{$D A_{t-1}$} & 2004-2006 & -0.36217 & 0.29019 & -0.055855 & -0.072137 & 0.12597 \\
\hline & 2011-2014 & -0.38395 & 0.28003 & -0.051411 & -0.052735 & 0.082458 \\
\hline \multirow{2}{*}{$\mathrm{NDA}_{\mathrm{t}-1}$} & 2004-2006 & -0.27436 & 0.37768 & 0.12269 & 0.13348 & 0.12423 \\
\hline & 2011-2014 & -0.26365 & 0.37481 & 0.031647 & 0.033741 & 0.062865 \\
\hline
\end{tabular}

Source: Elaborated by the authors.

It was also verified, in tables 3 and 4 , that the means and medians of the DAs derived from the Kothari et al. (2005) and Dechow et al. (2012) models were negative in the periods before and after IFRS adoption in Brazil. In turn, the means and medians of the NDAs derived from these models in those two periods were positive.
Since the mean of the total ACCs was positive in the period before convergence with IFRS in Brazil, it is possible to say that, in magnitude, the mean of the NDAs exceeded the mean of the DAs in the two ACC estimation models employed. In contrast, since the mean of the total ACCs was negative in the period 
after convergence with IFRS in Brazil, it is possible to say that, in magnitude, the mean of the NDAs was below the mean of the DAs in the two ACC estimation models used in the research, also corroborating with the findings of Silva (2015).

Statistical summaries of the ACC estimation models (Dechow et al., 2012; Kothari et al., 2005) are presented in Table 5. It was verified that before and after the employment of IFRS, the variables (except fixed assets after IFRS adoption) and the analyzed models themselves were statistically significant at a level of $5 \%$.

Given the adjusted $\mathrm{R}^{2}$, it is found that the Kothari et al. (2005) model had a slightly greater ability to explain total ACCs in relation to the Dechow et al. (2012) model before accounting convergence in Brazil. In contrast, the Dechow et al. (2012) model had a greater ability to explain total ACCs in relation to the Kothari et al. (2005) model after IFRS adoption.

\section{Table 5}

Results of the multiple regressions of the total accruals estimation models

\begin{tabular}{|c|c|c|c|c|c|c|c|c|}
\hline \multirow[b]{3}{*}{ Variables } & \multicolumn{4}{|c|}{ Kothari et al. (2005) model } & \multicolumn{4}{|c|}{ Dechow et al. (2012) model } \\
\hline & \multicolumn{2}{|c|}{ Before IFRS } & \multicolumn{2}{|c|}{ After IFRS } & \multicolumn{2}{|c|}{ Before IFRS } & \multicolumn{2}{|c|}{ After IFRS } \\
\hline & Coefficient & p-value & Coefficient & p-value & Coefficient & p-value & Coefficient & p-value \\
\hline Intercept & $0.0163 *$ & 0.0000 & $-0.0306^{*}$ & 0.0000 & $0,0231^{*}$ & 0,0000 & $-0,0125^{*}$ & 0,0000 \\
\hline$\Delta \operatorname{Rev}_{\mathrm{t}}-\Delta \mathrm{AC}_{\mathrm{t}}$ & $0.0745^{*}$ & 0.0002 & $-0.0552^{* *}$ & 0.0149 & $0,0841^{*}$ & 0,0000 & $-0,0427^{* *}$ & 0,0173 \\
\hline $\mathrm{FA}_{\mathrm{t}}$ & $0.0203 *$ & 0.0033 & -0.0024 & 0.6502 & $0,0205^{*}$ & 0,0014 & $-0,0052$ & 0,2454 \\
\hline $\mathrm{ROA}_{\mathrm{t}-1}$ & $0.5540^{*}$ & 0.0000 & $0.0877^{*}$ & 0.0033 & & & & \\
\hline $\mathrm{ACC}_{\mathrm{t}-1}$ & & & & & $0,4987^{*}$ & 0,0000 & $0,4395^{*}$ & 0,0000 \\
\hline Adjusted $\mathrm{R}^{2}$ & \multicolumn{2}{|c|}{0.309281} & \multicolumn{2}{|c|}{0.010058} & \multicolumn{2}{|c|}{0.309187} & \multicolumn{2}{|c|}{0.213634} \\
\hline F test (p-value) & \multicolumn{2}{|c|}{0.0000} & \multicolumn{2}{|c|}{0.002795} & \multicolumn{2}{|c|}{0.0000} & \multicolumn{2}{|c|}{0.0000} \\
\hline Schwarz & \multicolumn{2}{|c|}{$-3,353.065$} & \multicolumn{2}{|c|}{$-4,933.472$} & \multicolumn{2}{|c|}{$-3,489.374$} & \multicolumn{2}{|c|}{$-5,364.704$} \\
\hline Akaike & \multicolumn{2}{|c|}{$-3,373.163$} & \multicolumn{2}{|c|}{$-4,955.314$} & \multicolumn{2}{|c|}{$-3,509.501$} & \multicolumn{2}{|c|}{$-5,386.541$} \\
\hline Observations (n) & \multicolumn{2}{|c|}{1,124} & \multicolumn{2}{|c|}{1,738} & \multicolumn{2}{|c|}{1,132} & \multicolumn{2}{|c|}{1,736} \\
\hline
\end{tabular}

Note: due to the heteroskedasticity problem of the residuals (Breusch-Pagan test), robust standard errors were used, except for the Dechow et al. (2012) model after IFRS.

*,**,***: significant at 1,5 , and $10 \%$, respectively.

Source: Elaborated by the authors.

In Table 5, a reduction is found in the adjusted $R^{2}$ in both models in the period after IFRS adoption in comparison with the period before convergence with IFRS, indicating an increase in the error. So, it is possible to infer that there was an increase in the DAs in the period after IFRS adoption, which indicates greater earnings management and is consistent with the results of Silva (2015). Yet, in light of this result, it is still not possible to describe the nature of the earnings management, that is, whether it is opportunist/contractual or informational.

Regarding the normality of the residuals, the JarqueBera rejected the null hypothesis in the Kothari et al. (2005) ) model before ( $\mathrm{p}$-value $=0.0000$ ) and after ( $\mathrm{p}$-value $=0.0000)$ IFRS and also in the Dechow et al. (2012) model before $(p$-value $=0.0000)$ and after $(p$-value $=$ $0.0000)$ convergence with IFRS. However, according to the central limit theorem and considering the large quantity of observations used, the normality assumption can be relaxed (Brooks, 2002). The values of the VIF (variance inflation factor) test were lower than 5 before and after the IFRS convergence period in the two models mentioned, indicating the absence of multicollinearity.

\subsection{Cash Flow Estimation Models - DA and NDA}

Next, in tables 6 and 7 the statistical summaries of models 1, 2, 3, and 4 are described. The results presented consider the exclusion of outliers. In Kothari et al. (2005) models 1 and 3, using the interquartile range, 804 observations were removed, leaving 2,785. In Dechow et al. (2012) models 1 and 3, a total of 926 observations were removed, remaining 2,663. In models 2 and 4 , a total of 1,718 observations were removed, remaining 3,287.

As shown in Table 6, with regards to the DAs and NDAs in the periods before and after IFRS, it is found that DA in Dechow et al. (2012) model 1 is positive and statistically significant at a level of 5\%. As for ACC, in model 2 it is negative and statistically significant at a level of $5 \%$. These results indicate that the aggregate ACCs and DA have predictive power in relation to future OCFs.

Possible explanations for this positive relationship between the results of current accounting choices/estimates and future OCFs could be the targeting or maintenance of results at certain levels in order to favor certain 
interests (opportunistic/contractual aspect of earnings management) or to even disclose faithful information about the economic phenomenon to be represented (informational aspect of earnings management). This relationship tends to become clearer with the presentation of the results separated between the periods before and after convergence with IFRS in Brazil.
In addition, the adjusted $\mathrm{R}^{2}$ of the Kothari et al. (2005) and Dechow et al. (2012) models 1 were higher than that of model 2, indicating the non-rejection of $\mathrm{H}_{1}$ of this study, despite the values of the Akaike and Schwarz informational criteria of model 2 being lower than those of models 1.

Table 6

Results of the regression of models 1 and 2

\begin{tabular}{|c|c|c|c|c|c|c|}
\hline \multirow[b]{2}{*}{ Variables } & \multicolumn{2}{|c|}{$\begin{array}{c}\text { Model } 1 \text { - } \\
\text { Kothari et al. (2005) }\end{array}$} & \multicolumn{2}{|c|}{$\begin{array}{c}\text { Model } 1 \text { - } \\
\text { Dechow et al. (2012) }\end{array}$} & \multicolumn{2}{|c|}{ Model 2} \\
\hline & Coefficient & p-value & Coefficient & p-value & Coefficient & p-value \\
\hline Intercept & $0.0197^{*}$ & 0.0000 & $0.0209^{*}$ & 0,0000 & $0,0233^{*}$ & 0,0000 \\
\hline $\mathrm{OCF}_{\mathrm{t}-1}$ & $0.7119 *$ & 0.0000 & $0.7005^{*}$ & 0,0000 & $0,6271^{*}$ & 0,0000 \\
\hline $\mathrm{ACC}_{\mathrm{t}-1}$ & & & & & $-0,1017^{*}$ & 0,0000 \\
\hline $\mathrm{DA}_{\mathrm{t}-1}$ & 0.0254 & 0.1277 & $0.0447^{* *}$ & 0,0194 & & \\
\hline $\mathrm{NDA}_{\mathrm{t}-1}$ & $-0.0314 * * *$ & 0.0563 & -0.0270 & 0,1450 & & \\
\hline Adjusted $\mathrm{R}^{2}$ & \multicolumn{2}{|c|}{0.554044} & \multicolumn{2}{|c|}{0.546093} & \multicolumn{2}{|c|}{0.512158} \\
\hline $\mathrm{F}$ test (p-value) & \multicolumn{2}{|c|}{0.0000} & \multicolumn{2}{|c|}{0.0000} & \multicolumn{2}{|c|}{0.0000} \\
\hline Schwarz & \multicolumn{2}{|c|}{$-9,504.781$} & \multicolumn{2}{|c|}{$-9,002.424$} & \multicolumn{2}{|c|}{$-10,993.75$} \\
\hline Akaike & \multicolumn{2}{|c|}{$-9,528.509$} & \multicolumn{2}{|c|}{$-9,025.973$} & \multicolumn{2}{|c|}{$-11,012.05$} \\
\hline Observations (n) & \multicolumn{2}{|c|}{2,785} & \multicolumn{2}{|c|}{2,663} & \multicolumn{2}{|c|}{3,287} \\
\hline
\end{tabular}

Note: due to the heteroskedasticity problem of the residuals (Breusch-Pagan test), robust standard errors were used. *,**,**: significant at 1, 5, and 10\%.

Source: Elaborated by the authors.

With regards to the normality of the residuals, the Jarque-Bera test rejected the null hypothesis in the Kothari et al. $(2005)(\mathrm{p}$-value $=0.0000)$ and Dechow et al. (2012) ( $\mathrm{p}$-value $=0.0000)$ model $1 \mathrm{~s}$, as well as in model 2 ( $p$-value $=0.0000)$. In contrast, according to the central limit theorem and given the substantial quantity of observations, the normality assumption can be relaxed (Brooks, 2002). The values of the VIF test, however, were lower than 5 in the models mentioned, showing the absence of multicollinearity.

Next, in Table 7, statistical summaries of Kothari et al. (2005) and Dechow et al. (2012) models 3 and of model 4 are provided. It was identified that the DAs and NDAs in the period before IFRS were negative and statistically significant. It was also discovered that in these model $3 \mathrm{~s}$, the DAs and NDAs were positive and statistically significant in the period after the implementation of IFRS. These results indicate that the DAs and NDAs are reversed in future OCFs, in opposite ways, depending on the period analyzed (before or after convergence with IFRS).

Given that the values of the coefficients of DA after IFRS (0.0725 and 0.1000) in models 3 are higher than the value of the coefficient of DA (0.0447) for the total analysis period, in Dechow et al. (2012) model 1 it is interpreted that there is a greater contribution from the results derived from the accounting choices/estimates employed by accountants and managers after IFRS for predicting future OCFs. So, there appears to be a decrease or reduction in the perception of stakeholders in the Brazilian stock market regarding informational risk. With this, an image is presented that there is an apparent increase in the relevance and in the reliability of the accounting information communicated to these stakeholders due to the improvement in predictive utility.

In addition, since the coefficient of the aggregate ACCs (-0.091) before the IFRS implementation period in Brazil, in model 4 , was lower than the coefficient of the aggregate ACCs (-0.1017) for the total analysis period, in model 2, it is interpreted that there is not a greater contribution for predicting future OCFs from the aggregate ACCs before IFRS.

Using the Chow test, in order to examine whether the intercept or the angular coefficients of the regression remained statistically stable after convergence with IFRS in Brazil, rejection of the null hypothesis was verified, given that the p-values of the Kothari et al. (2005) and Dechow et al. (2012) models 3, as well as model 4, were equal to 0.0000 . So, there was a structural break; that 
is, the parameters presented statistical instability of the sample before to the sample after IFRS adoption, which reinforces the indication that the accounting variables were positively impacted by IFRS adoption in Brazil.

The adjusted $\mathrm{R}^{2}$ of the abovementioned model 3 s were higher than the adjusted $\mathrm{R}^{2}$ of model 4 , although the values of the Akaike and Schwarz informational criteria of model 4 were lower than the values of these criteria in the models 3. In contrast, the coefficients of the DAs and NDAs in the model 3s originating after complete convergence with IFRS in Brazil were higher that the coefficients of the DAs and NDAs in the models 1, and the Chow test indicated a structural break from the samples. Therefore, it is inferred that the current disaggregated ACCs, originating after IFRS adoption in Brazil (from 2010), add informational power in relation to the current aggregate ACCs, thus not rejecting $\mathrm{H}_{2}$ of this study.

In addition, given the adjusted $\mathrm{R}^{2}$ and the Akaike and Schwarz informational criteria, the Kothari et al. (2005) model produces better information with regards to DA and NDA in terms of estimating future cash flows in relation to the Dechow et al. (2012) model.

Table 7

Results of the regression of models 3 and 4

\begin{tabular}{|c|c|c|c|c|c|c|}
\hline \multirow[b]{2}{*}{ Variables } & \multicolumn{2}{|c|}{$\begin{array}{c}\text { Model } 3 \text { - } \\
\text { Kothari et al. (2005) }\end{array}$} & \multicolumn{2}{|c|}{$\begin{array}{c}\text { Model 3 - } \\
\text { Dechow et al. (2012) }\end{array}$} & \multicolumn{2}{|c|}{ Model 4} \\
\hline & Coefficient & p-value & Coefficient & p-value & Coefficient & p-value \\
\hline Intercept & 0.0193* & 0.0000 & $0.0219^{*}$ & 0.0000 & $0.0236^{*}$ & 0.0000 \\
\hline $\mathrm{OCF}_{\mathrm{t}-1}$ & $0.6855^{*}$ & 0.0000 & $0.5981^{*}$ & 0.0000 & $0.4558^{*}$ & 0.0000 \\
\hline $\mathrm{OCF}_{\mathrm{t}-1} \times$ IFRS & 0.0257 & 0.5701 & 0.1191* & 0.0027 & $0.1746^{*}$ & 0.0000 \\
\hline $\mathrm{DA}_{\mathrm{t}-1}$ & $-0.0223^{* *}$ & 0.0152 & $-0.0489 *$ & 0.0000 & & \\
\hline $\mathrm{DA}_{\mathrm{t}-1} \times \mathrm{IFRS}$ & $0.0948^{*}$ & 0.0005 & $0.1489 *$ & 0.0000 & & \\
\hline $\mathrm{NDA}_{\mathrm{t}-1}$ & $-0.0769 *$ & 0.0000 & $-0.0912^{*}$ & 0.0000 & & \\
\hline $\mathrm{NDA}_{\mathrm{t}-1} \times \mathrm{IFRS}$ & $0.1530 *$ & 0.0000 & $0.1063 *$ & 0.0003 & & \\
\hline $\mathrm{ACC}_{\mathrm{t}-1}$ & & & & & $-0.0910^{*}$ & 0.0065 \\
\hline $\mathrm{ACC}_{\mathrm{t}-1} \times \mathrm{IFRS}$ & & & & & -0.0072 & 0.7797 \\
\hline Adjusted $\mathrm{R}^{2}$ & \multicolumn{2}{|c|}{0.559589} & \multicolumn{2}{|c|}{0.551132} & \multicolumn{2}{|c|}{0.513395} \\
\hline $\mathrm{F}$ test (p-value) & \multicolumn{2}{|c|}{0.000000} & \multicolumn{2}{|c|}{0.000000} & \multicolumn{2}{|c|}{0.000000} \\
\hline Schwarz & \multicolumn{2}{|c|}{$-9,518.841$} & \multicolumn{2}{|c|}{$-9,011.496$} & \multicolumn{2}{|c|}{$-10,987.90$} \\
\hline Akaike & \multicolumn{2}{|c|}{$-9,560.365$} & \multicolumn{2}{|c|}{$-9,052.707$} & \multicolumn{2}{|c|}{$-11,018.39$} \\
\hline Observations (n) & \multicolumn{2}{|c|}{2,785} & \multicolumn{2}{|c|}{2,663} & \multicolumn{2}{|c|}{3,287} \\
\hline
\end{tabular}

Note: due to the heteroskedasticity problem of the residuals (Breusch-Pagan test), robust standard errors were used. *,**,**: significant at 1, 5, and 10\%.

Source: Elaborated by the authors.

With regards to the normality of the residuals, the Jarque-Bera test rejected the null hypothesis in the Kothari et al. (2005) (p-value $=0.0000)$ and Dechow et al. (2012) (p-value $=0.0000)$ models 3 , as well as in model 4 ( $\mathrm{p}$-value $=0.0000)$. In spite of this, according to the central limit theorem and given the considerable quantity of observations, the normality assumption may be attenuated (Brooks, 2002).

With regards to the values of the VIF test, in models 3 and 4 there were variables with values higher than 5, showing the presence of multicollinearity. In Kothari et al. (2005) model 3, the variables were: $\mathrm{OCF}_{\mathrm{t}-1}, \mathrm{OCF}_{\mathrm{t}-1} \times$ IFRS, and $\mathrm{AD}_{\mathrm{t}-1} \times$ IFRS. As for Dechow et al. (2012) model 3, the variables were: $\mathrm{OCF}_{\mathrm{t}-1}, \mathrm{AD}_{\mathrm{t}-1}, \mathrm{OCF}_{\mathrm{t}-1} \times \mathrm{IFRS}$, and $\mathrm{AD}_{\mathrm{t}-1} \times$ IFRS. In model 4 , the variables were: $\mathrm{OCF}_{\mathrm{t}-1}$ and $\mathrm{OCF}_{\mathrm{t}-1} \times$ IFRS.

\subsection{Summary and Discussion of the Results}

In light of the results presented in this study, it is possible to affirm that DA and NDA contributed to predicting future OCFs before IFRS adoption in Brazil in a statistically significant way and with a negative sign. In contrast, DA and NDA contribute to predicting future OCFs after IFRS adoption in Brazil in a statistically significant way with a positive sign.

Given that the DAs and NDAs, notably in relation to assets, positively relate with the future cash flows of companies in the Brazilian stock market in a short space of time (next accounting period), it is possible to infer that the propagated ability to generate future economic benefits would be reasonably well represented with IFRS adoption, despite the inherent subjectivities, imprecisions, and uncertainties related to the accounting measurement process and to the economic environment. 
Therefore, this study presents indications that the accounting choices, in the Brazilian stock market, enabled by IFRS based eminently on principles, contribute to an apparent improvement in the quality of accounting information in terms of reliability, the faithful representation of entities's equity and financial positions, and in particular, the predictive utility for estimating future cash flows. Thus, this study is consistent with the results of Santos and Cavalcante (2014).

Finally, as illustrated by Dechow, Ge, and Schrand (2010), who carried out a compilation of studies on voluntary disclosure and accounting quality, some positive consequences from a practical point of view are highlighted in relation to the improvement in the quality of accounting information: minimization of costs of judicial litigation, of independent auditors, and of own and third party capital to fund activities, and an increase in the credibility of the market in companies and in the analyses produced by financial analysts, among others. Future studies in Brazil could investigate whether these consequences do in fact occur in practice.

\section{FINAL REMARKS}

This study analyzed and evaluated the predictive ability of DA and NDA in forecasting future OCFs before and after the convergence with IFRS in Brazil. The DAs and NDAs produced before complete convergence with IFRA are negative and statistically significant for predicting future cash flows in the Brazilian stock market.

Thus, these results indicate that there was earnings management of the opportunistic/contractual type, that is, with high informational risks, because the accounting choices did not represent the real economic performance of the company, possibly favoring own interests to the detriment of other stakeholders, as suggested by Teoh et al. (1998), Dechow and Skinner (2000), and Badertscher et al. (2012). One of the possible explanations for this would be the influence of the tax authorities on Brazilian accounting norms, which could induce managers to manipulate accounting results with the aim of reducing earnings in order to pay fewer taxes, for example.

As for the DAs and NDAs produced after complete convergence, these are positive and statistically significant for predicting future cash flows in the Brazilian stock market. Thus, there are indications that the managers of the companies listed on the BM\&FBovespa are currently motivated to use discretionary accounting choices under the informational aspect highlighted by Subramanyam (1996) and Badertscher et al. (2012). So, the flexibilities of the accounting norms may be being used to decrease or reduce the perception of stakeholders in the Brazilian stock market regarding the informational risks. With this, an image is presented that there is an apparent increase in the relevance and in the reliability of the accounting information communicated to these stakeholders due to the improvement in predictive utility.

Unlike Olfa and Hamadi (2015), who did not find any statistical significance in companies from France, a code-law country like Brazil, in the Brazilian stock market there was a positive impact of DAs for estimating future cash flows after IFRS adoption.

Given the adjusted $\mathrm{R}^{2}$ of models 1 and 2 (despite the values of the Akaike and Schwarz informational criteria), it is possible to state that $\mathrm{H}_{1}$ was not rejected; that is, the current ACCs disaggregated into DA and NDA, originating from the Kothari et al. (2005) and Dechow et al. (2012) models, add informational power in comparison with the current aggregate ACCs.

It is also understood that $\mathrm{H}_{2}$ was not rejected; that is, the current ACCs disaggregated into DA and NDA, derived from the Kothari et al. (2005) and Dechow et al. (2012) models and originating after complete convergence with IFRS in Brazil (from 2010), in comparison with the current aggregate ACCs, have an informational gain in relation to those produced before, especially given the adjusted $\mathrm{R}^{2}$ of model 3 in relation to model 4 and the coefficients of DA and NDA after the adoption of IFRS of the model $3 \mathrm{~s}$ in relation to the model $1 \mathrm{~s}$.

There is evidence that the IFRS applied in Brazil provided apparent improvements in the quality of the accounting information produced by companies listed on the BM\&FBovespa. Notably, the predictive ability of the ACCs in estimating future cash flows increased.

Among the main contributions from this study, the following stand out: (i) the revelation of the positive contribution from the DAs for estimating future cash flows, especially in the period after the adoption of IFRS; and (ii) a strengthening of the argument that there is an apparent informational gain after complete convergence with IFRS - that is, the quality of the accounting information appears to have been increased in the Brazilian stock market, which would benefit stakeholders who use accounting statements for decision making.

In light of the indications presented in this study, future research could carry out additional tests to verify earnings 
management of the informational or opportunistic/ contractual type by means of, for example, the addition of control variables to the models employed, such as size (natural logarithm of total assets), market-to-book, and indebtedness.

Future studies could also deepen the investigation regarding the influence of DA, especially by verifying which accounting choices effectively contribute to the estimation of future cash flows. This analysis could occur by industry, with the expansion of the sample to other years and collating the results with international studies in code-law and common-law environments.

Future studies could also discuss and propose new ACC estimation models, especially for calculating DAs, given that some of the variables in the models analyzed in this study, such as fixed assets, involve a considerable degree of discretion, especially in countries that have adopted IFRS, such as Brazil, which may interfere in the results and not satisfactorily portray the underlying economic and accounting reality of the corporate environment.

\section{REFERENCES}

Ahmed, A. S., Neel, M., \& Wang, D. (2013). Does mandatory adoption of IFRS improve accounting quality? Preliminary evidence. Contemporary Accounting Research, 30(4), 13441372.

Badertscher, B. A., Collins, D. W., \& Lys, T. Z. (2012). Discretionary accounting choices and the predictive ability of accruals with respect to future cash flows. Journal of Accounting and Economics, 53(1-2), 330-352.

Barth, M. E., Cram, D. P., \& Nelson, K. K. (2001). Accruals and the prediction of future cash flows. The Accounting Review, 76(1), 27-58.

Barth, M. E., Landsman, W. R., \& Lang, M. H. (2008). International accounting standards and accounting quality. Journal of Accounting Research, 46(3), 467-498.

Biddle, G. C., Seow, G. S., \& Siegel, A. F. (1995). Relative versus incremental information content. Contemporary Accounting Research, 12(1), 1-23.

Boina, T. M., Martins, A. M., Costa, J. A. V., \& Macedo, M. A. S. (2016a). Estimação de fluxos de caixa de empresas concessionárias do setor brasileiro de energia elétrica. Paper presented at the $20^{\text {th }}$ Brazilian Accounting Congress. Retrieved from http://cbc.cfc.org.br/comitecientifico/images/ stories/trabalhos/360C.pdf

Boina, T. M., Jesus, L. F., Soares, J. E. V. M., \& Macedo, M. A. S. (2016b). Avaliação da capacidade preditiva do lucro líquido, do fluxo de caixa operacional e dos accruals antes e após a convergência às normas internacionais de contabilidade no Brasil. Trabalho apresentado no XVI Congresso USP de Controladoria e Contabilidade. Paper presented at the XVI USP Controlling and Accounting Congress. Retrieved from http://www.congressousp.fipecafi.org/anais/ artigos162016/143.pdf

Brochet, F., Nam, S., \& Ronen, J. (2007). The role of accruals in predicting future cash flows and stock returns [Working Paper]. AAA Annual Meeting. Retrieved from https://pdfs.semanticscholar.org/ed63/ e1b790c3fef8124ff9c6547b03972a08dc19.pdf

Brooks, C. (2002). Introductory econometrics for finance. Cambridge: Cambridge University Press.

Burgstahler, D. C., Hail, L., \& Leuz, C. (2006). The importance of reporting incentives: earnings management in European private and public firms. The Accounting Review, 81(5), 9831016.
Chaney, P. K., Faccio, M., \& Parsley, D. (2011). The quality of accounting information in politically connected firms. Journal of Accounting and Economics, 51(1-2), 58-76.

Chen, H., Tang, Q., Jiang, Y., \& Lin, Z. (2010). The role of international financial reporting standards in accounting quality: evidence from the European Union. Journal of International Financial Management \& Accounting, 21(3), 220-278.

Christensen, P. O., Frimor, H., \& Sabac, F. (2012). The stewardship role of analyst forecasts, and discretionary versus nondiscretionary accruals. European Accounting Review, 22(2), 257-296.

Comissão de Valores Mobiliários. (2005). Deliberação CVM $n$. 488, de 3/10/2005. Aprova o Pronunciamento do IBRACON NPC $n^{\circ} 27$ sobre demonstrações contábeis - Apresentação e divulgações. Retrieved from http://www.cvm.gov.br/export/ sites/cvm/legislacao/deli/anexos/0400/deli488.pdf

Comitê de Pronunciamentos Contábeis. (2011). CPC 26 (R1) Apresentação das demonstrações contábeis. Retrieved from http://static.cpc.mediagroup.com.br/Documentos/312_ CPC_26_R1_rev\%2008.pdf

Costa, J. A., \& Afonso, L. E. (2015). O valor preditivo do resultado líquido contábil, dos accruals e do fluxo de caixa operacional das seguradoras. Paper presented at the XV USP Controlling and Accounting Congress. Retrieved from http://www. congressousp.fipecafi.org/anais/artigos152015/55.pdf

Dechow, P. M., \& Dichev, I. D. (2002). The quality of accruals and earnings: the role of accrual estimation errors (Supplement). The Accounting Review, 77, 35-59.

Dechow, P. M., \& Schrand, C. M. (2004). Earnings quality. Charlottesville, VA: Research Foundation of CFA Institute. Retrieved from http://csinvesting.org/wp-content/ uploads/2015/04/Defining-Earnings-Quality-CFAPublication.pdf

Dechow, P. M., \& Skinner, D. J. (2000). Earnings management: reconciling the views of accounting academics, practitioners, and regulators. Accounting Horizons, 14(2), 235-250.

Dechow, P. M., Ge, W., \& Schrand, C. M. (2010). Understanding earnings quality: a review of the proxies, their determinants and their consequences. Journal of Accounting and Economics, 50(2-3), 344-401.

Dechow, P. M., Hutton, A. P., Kim, J. H., \& Sloan, R. G. (2012). Detecting earnings management: a new approach. Journal of Accounting Research, 50(2), 275-334. 
Dechow, P. M., Kothari, S. P., \& Watts, R. L. (1998). The relation between earnings and cash flows. Journal of Accounting and Economics, 25(2), 133-168.

Ebaid, I. El-S. (2011). Accruals and the prediction of future cash flows: empirical evidence from an emerging market. Management Research Review, 34(7), 838-853.

Farshadfar, S., Ng, C., \& Brimble, M. (2008). The relative ability of earnings and cash flow data in forecasting future cash flows: some Australian evidence. Pacific Accounting Review, 20(3), 254-268.

Fávero, L. P., Belfiore, P., Silva, F. L. da, \& Chan, B. L. (2009). Análise de dados: modelagem multivariada para tomada de decisões. Rio de Janeiro, RJ: Elsevier.

Fields, T. D., Lys, T. Z., \& Vicent, L. (2001). Empirical research on accounting choice. Journal of Accounting and Economics, 31(1-3), 255-307.

Financial Accounting Standards Board. (1978). Statement of Financial Accounting Concepts $n$. 1. Objectives of financial reporting by business enterprises. Stamford, CT: FASB.

Finger, C. A. (1994). The ability of earnings to predict future earnings and cash flow. Journal of Accounting Research, 32(2), 210-223.

Guay, W. R., Kothari, S. P., \& Watts, R. L. (1998). A market-based evaluation of discretionary accrual models [Supplement]. Journal of Accounting Research, 34, 83-105.

Healy, P. M., \& Wahlen, J. M. (1999). A review of the earnings management literature and its implications for standard setting. Accounting Horizons, 13(4), 365-383.

Hribar, D. W., \& Collins, P. (2002). Errors in estimating accruals: implications for empirical research. Journal of Accounting Research, 40(1), 105-134.

Kim, M., \& Kross, W. (2005). The ability of earnings to predict future operating cash flows has been increasing - not decreasing. Journal of Accounting Research, 43(5), 753-780.

Kothari, S. P., Leone, A. J., \& Wasley, C. E. (2005). Performance matched discretionary accrual measures. Journal of Accounting and Economics, 39(1), 163-197.

Lopes, A. B., \& Martins, E. (2007). Teoria da contabilidade: uma nova abordagem. São Paulo, SP: Atlas.

Machado, M. A. V., Silva Filho, A. C. C., \& Callado, A. L. C. (2014). O processo de convergência às IFRS e a capacidade do lucro e do fluxo de caixa em prever os fluxos de caixa futuro: evidências no mercado brasileiro. Revista de Contabilidade e Organizações, 21(2014), 4-13.

Malacrida, M. J. C., Yamamoto, M. M., Lima, I. S., Lima, G. A. S. F. (2008). A relevância da demonstração do fluxo de caixa para o mercado de capitais brasileiro. Paper presented at the XXXII ANPAD Meeting. Retrieved from http://www.anpad.org.br/ admin/pdf/CON-A896.pdf

Martinez, A. L. (2013). Gerenciamento de resultados no Brasil: um survey da literatura. Brazilian Business Review, 10(4), $1-31$.
Martinez, A. L., \& Cardoso, R. C. (2009). Gerenciamento da informação contábil no Brasil mediante decisões operacionais. Revista Eletrônica de Administração, 15(3), 600-626.

Olfa, B. J., \& Hamadi, M. (2015). The impact of the IAS/IFRS adoption on the predictive quality of discretionary accruals: a comparison between the French and the British context. International Journal of Economics and Finance, 7(6), 208-231.

Paton, W. A., \& Littleton, A. C. (1940). An introduction to corporate accounting standards. Chicago, IL: American Accounting Association.

Paulo, E. (2007). Manipulação das informações contábeis: uma análise teórica e empírica sobre os modelos operacionais de detecção de gerenciamento de resultados (Doctoral thesis, Accounting Sciences, University of São Paulo, São Paulo.

Paulo, E., Girão, L. F. A. P., Carter, D., \& Souza, R. (2013). The impact of the adoption of International Financial Reporting Standards about the quality of accounting information of the Brazilian and European public firms. Paper presented at the VII ANPCONT. Retrieved from http://congressos.anpcont. org.br/congressos-antigos/vii/images/engltrack_4bfc3. pdf?20150429112300

Paulo, E., Martins, E., \& Corrar, L. J. (2007). Detecção do gerenciamento de resultados pela análise do diferimento tributário. RAE, 47(1), 46-59.

PriceWaterhouseCoopers. (2015). Fusões e Aquisições no Brasil. Retrieved from https://www.pwc.com.br/pt/publicacoes/ servicos/assets/fusoes-aquisicoes/2015/pwc-fusoesaquisicoes-setembro-15.pdf

Santos, M. A. C. dos, \& Cavalcante, P. R. N. (2014). O Efeito da adoção dos IFRS sobre a relevância informacional do lucro contábil no Brasil. Revista de Contabilidade \& Finanças, 25(66), 228-241.

Silva, R. L. M. (2013). Adoção completa das IFRS no Brasil: qualidade das demonstrações contábeis e o custo de capital próprio (Doctoral thesis, Accounting Sciences, University of São Paulo, São Paulo).

Silva, V. C. da. (2015). A adoção das IFRS impacta no gerenciamento de resultados? Evidências do mercado de capitais brasileiro (Master's dissertation, Accouting Sciences, Federal University of Espírito Santo, Vitória).

Sloan, R. G. (1996). Do stock prices fully reflect information in accruals and cash flows about future earnings? The Accounting Review, 71(3), 289-315.

Subramanyam, K. R. (1996). The pricing of discretionary accruals. Journal of Accounting and Economics, 22(1), 249-281.

Tendeloo, B. V., \& Vanstraelen, A. (2005). Earnings management under German GAAP versus IFRS. European Accounting Review, 14(1), 155-180.

Teoh, S. H., Welch, I., \& Wong, T. J. (1998). Earnings management and the long run market performance of initial public offerings. The Journal of Finance, 53(6), 1935-1974.

Watts, R. L., \& Zimmerman, J. L. (1986). Positive accounting theory. Upper Saddle River, NJ: Prentice-Hall. 